\title{
The predator-prey model on squids and anchovies fisheries in Jepara District, Central Java, Indonesia
}

\author{
DIAN WIJAYANTO", AZIS N. BAMBANG, FAIK KUROHMAN \\ Faculty of Fisheries and Marine Science, Universitas Diponegoro. Jl. Prof. Soedharto, Kampus Undip Tembalang, Semarang 50275, Central Java, \\ Indonesia. Tel./fax.: +62-24-7474698, `email: dianwijayanto@gmail.com
}

Manuscript received: 18 September 2020. Revision accepted: 21 November 2020.

\begin{abstract}
Wijayanto D, Bambang AN, Kurohman F. 2020. The predator-prey model on squids and anchovies fisheries in Jepara District, Central Java, Indonesia. Biodiversitas 21: 5697-5702. Traditional fisheries dominate marine fisheries in Jepara District, Central Java, Indonesia, including the lift net. The catch of the lift net includes squids and anchovies. The ecological relationship between squids and anchovies must be investigated to develop squids and anchovies management. Without proper modeling, the management of anchovies and squids can lead to over-exploitation of both types of commodities. This study aimed to develop the predator-prey model of squids and anchovies fish in the Jepara District. We conducted predator-prey modeling in squids and anchovies using production and fishing effort data from 2010 to 2019. This research showed a predator-prey relationship between squids (as a predator) and anchovies (as prey) in Jepara District. The anchovy's production function follows the equation: $C_{A}=14,507 \mathrm{E}-51 \mathrm{E}^{2}+0.41 \mathrm{C}_{S}$ or $\mathrm{C}_{\mathrm{A}}=4,444 \mathrm{E}-15.49 \mathrm{E}^{2}$. The production function of squids follows the equation: $\mathrm{C}_{\mathrm{S}}=35,156 \mathrm{E}-124 \mathrm{E}^{2}-2.42 \mathrm{C}_{\mathrm{A}}$ or $\mathrm{C}_{\mathrm{S}}=24,385 \mathrm{E}-86 \mathrm{E}^{2}$. The optimal fishing effort for anchovies and squids production is 144 units of lift net and 141 units of lift net.
\end{abstract}

Keywords: Anchovies, CPUE, Jepara, predator-prey model, squids

\section{INTRODUCTION}

Traditional fisheries dominate marine fisheries in Jepara District, Central Java, Indonesia. Artisanal fisheries are small scale (excluding sport-fishing) or traditional fisheries (include fishing households) using a relatively small amount, capital, energy, and vessel size. Artisanal fisheries have short fishing trips (including one dayfishing) in the fishing ground near the shore (FAO 2016). According to DMF (Department of Marine and Fisheries) of Jepara District (2020), most of the fishers in Jepara District use outboard motorboats when carrying out fishing operations, namely 2772 units. Meanwhile, the number of boats used by fishers in Jepara District is 323 units, and boat without a motor is 40 units. The fishing gear used by fishers in Jepara District includes seine net, purse seine, gillnet, lift net, hand line, trap, and Muro-Ami. Fishers catch more than 30 types of marine fishery commodities from the Jepara District. So the conditions of capture fisheries on the coast of Jepara are multi-species and multigears.

Multi-species and multi-gear fisheries dominate artisanal fisheries in tropical marine waters (including in Jepara District). Therefore, artisanal fisheries are complicated because of species' interactions and between fishing gears (Pelletier et al. 2009; Wijayanto et al. 2019a; Wijayanto et al. 2019b). It is, therefore, requires proper management because there are many interests from many parties. Thus, multi-species fisheries research is needed to develop fisheries management policies, including in Jepara District.
Anchovies and squids are commodities sought by fishers from Jepara District. Indonesia's water holds several species of anchovy and squid. Both commodities have a high selling value. Hence, research on the relationship between anchovies and squids in Jepara District is necessary to manage anchovy and squid resources. Anchovies and squids are caught using a lift net. The use of lights in lift nets is widely used in various countries globally, including Indonesia (Solomon and Ahmed 2016). Anchovies are positive phototaxis fish (Susanto et al. 2017; Fuad et al. 2019) as well as squids (Ibrahim and Hajisamae 1999; Fitri et al. 2018). Fishers use a lamp aid to collect anchovies before lifting the net). The anchovies are also caught using the seine net, but the percentage of the gear is relatively small. Lift net is the main fishing gear for anchovies fishery in Jepara District, contributing around $99 \%$ of the fisheries production. Meanwhile, squids are caught by the purse seine, seine net, and lift net (DMF of Jepara District 2020).

Anchovies are plankton eaters, while the squids are a carnivore and cannibal (Fuad et al. 2019). According to Martins and Perez (2006), squid caught in a lift net because it is looking for food, namely anchovies which are gathered to the light on the lift net. Thus squids and anchovies have an ecological relationship, where squids play as predators and anchovies as the prey. Consequently, the implementation of the management of squids and anchovies must consider this predator-prey relationship. This study aimed to develop the predator-prey model of squids and anchovies fish in the Jepara District. Fisheries modeling can be used to explore the relationships between species and set fisheries management policy. Fisheries 
modeling should adapt to the availability of data. The incompleteness of the data can hamper fisheries modeling research, especially in developing countries (Wijayanto et al. 2020a). In this study, we develop a research model according to the availability of data.

\section{MATERIALS AND METHODS}

\section{Study area}

Our research location was in Jepara District, Central Java, Indonesia. According to Statistics of Jepara District (2020) from Indonesian Statistics (BPS), Jepara District is located at coordinates of $5^{\circ} 43^{\prime} 20.67^{\prime \prime}$ to $6^{\circ} 47^{\prime} 25.83^{\prime \prime}$ South latitude and $110^{\circ} 9^{\prime} 48.02^{\prime \prime}$ and $110^{\circ} 58^{\prime} 37.40^{\prime \prime}$ East longitude (Figure 1).

\section{Research data}

Our research used time-series data (production and fishing effort) from 2010 to 2019, published by DMF of Jepara District (2020).

\section{Research model}

Based on the Schaefer model, the production function of squids and anchovies follows the equation [1] and [2] (Schaefer 1957; Wijayanto et al. 2020a).

$$
\begin{aligned}
& C_{A}=a E-b E^{2} \\
& C_{S}=d E-e E^{2}
\end{aligned}
$$

$\mathrm{C}_{\mathrm{A}}$ is the production of anchovies in $\mathrm{kg} . \mathrm{C}_{\mathrm{S}}$ is the production of squids in $\mathrm{kg}$. We used the assumption if anchovies are one species of stock and squids are also one species stock. Notation E is a fishing tool (units of lift net). Lift net is used as the standard of the fishing effort. The notations $\mathrm{a}, \mathrm{b}, \mathrm{d}$, and $\mathrm{e}$ are constants. However, the equations [1] and [2] are used to assume that there is no ecological relation between anchovies and squids. Then, we used the equations [3] and [4] as the modified version of the equations [1] and [2] (Wijayanto et al. 2020a). The equations [3] and [4] assuming that there are ecological relation between anchovies (as prey) and squids (as predator).

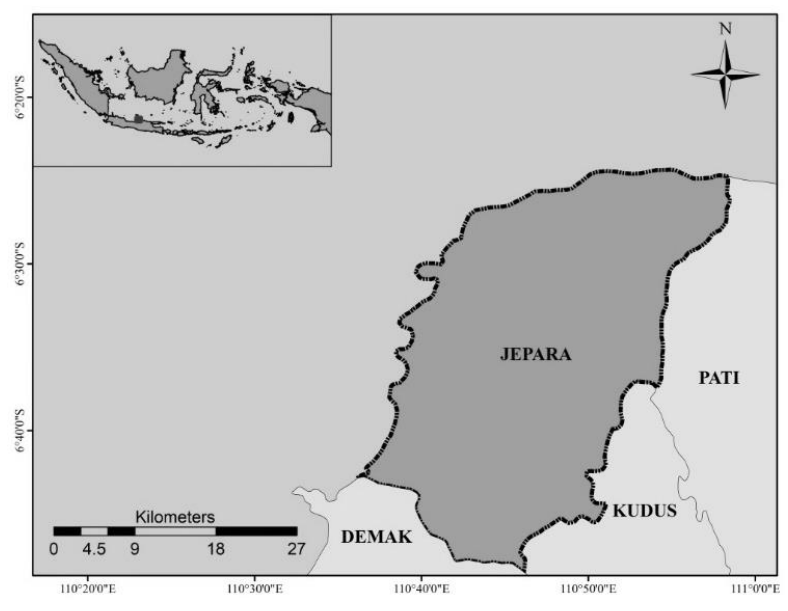

Figure 1. Map of Jepara District, Central Java, Indonesia

$$
\begin{aligned}
& C_{A}=a E-b E^{2}+f C_{S} \\
& C_{S}=d E-e E^{2}-g C_{A}
\end{aligned}
$$

The notations $\mathrm{f}$ and $\mathrm{g}$ are constants. The increase of squids production will decrease pressure on the stock of anchovies resources; then, the anchovies production can increase. Meanwhile, the increase of anchovy production will decrease food availability for squids, decreasing the squids' production. If equation [3] is added to equation [4], then equation [5] can be generated. Then, equation [5] can be modified into equations [6] and [7] as the predator-prey model. The optimization procedure to equation [6] and [7] generate equations [8] and [9].

$$
\begin{aligned}
& (1+g) C_{A}+(1-f) C_{S}=(a+d) E-(b+e) E^{2} \\
& C_{A}=\frac{a+d f}{1+g f} E-\frac{b+e f}{1+g f} E^{2} \\
& C_{S}=\frac{d-a g}{1+g f} E-\frac{e-b g}{1+g f} E^{2} \\
& E_{C_{A \max }}=\frac{a+d f}{2 b+2 e f} \\
& E_{C_{S \max }}=\frac{d-a g}{2 e-2 b g}
\end{aligned}
$$

After developing the research model, we processed the data using fisheries statistics for Jepara District (2010 to 2019). We regress the equation [3] and [4] with both sides divided by fishing effort (E) so that the equation becomes a linear equation. Therefore, the constants $a, b, d, e, f$, and $g$ can be known. In the next procedures, we used equations [3], [4], [6], [7], [8], and [9] to analyze the relationship between the production of anchovy and squid, including production maximization.

\section{RESULTS AND DISCUSSION}

\section{The production progress of anchovies and squids}

The progress of marine fisheries production in Jepara District is available in Figure 2, representing squids and anchovies' production, respectively. The total marine fisheries production of Jepara District has fluctuated and has an increasing trend. Meanwhile, anchovies and squids are experiencing a downward trend, but they increase from 2018 to 2019 . It showed that squid and anchovies' exploitation has led to a decline in the resource stocks, affecting the decline in production and productivity of squid and anchovy fisheries during 2010 and 2016. Anchovies and squids are only a small part of marine fisheries production in the Jepara District (Figure 3). The number of fishers in the Jepara District in 2019 was 8341 people (DMF of Jepara District 2020). The condition of the multi-gears, multi-species, dominated by artisanal fisheries and the relatively large number of fishers, greatly complicates the management of fisheries resources in Jepara District. 

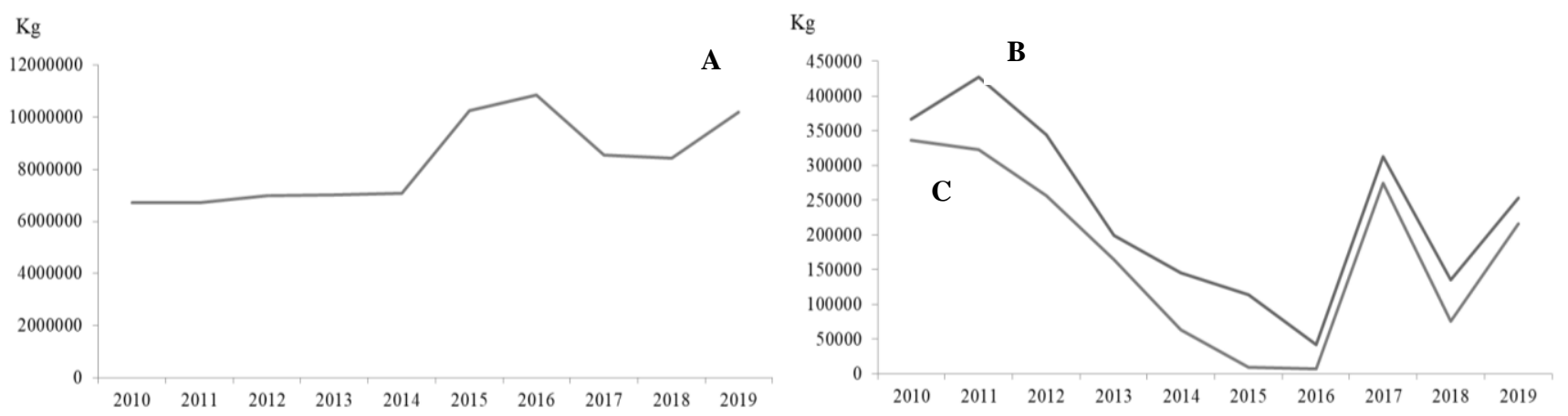

Figure 2. The progress of marine fisheries production in Jepara District, Central Java, Indonesia. Note: a. Total marine fisheries production; b. Squids production; c. Anchovies production (DMF of Jepara District 2020)

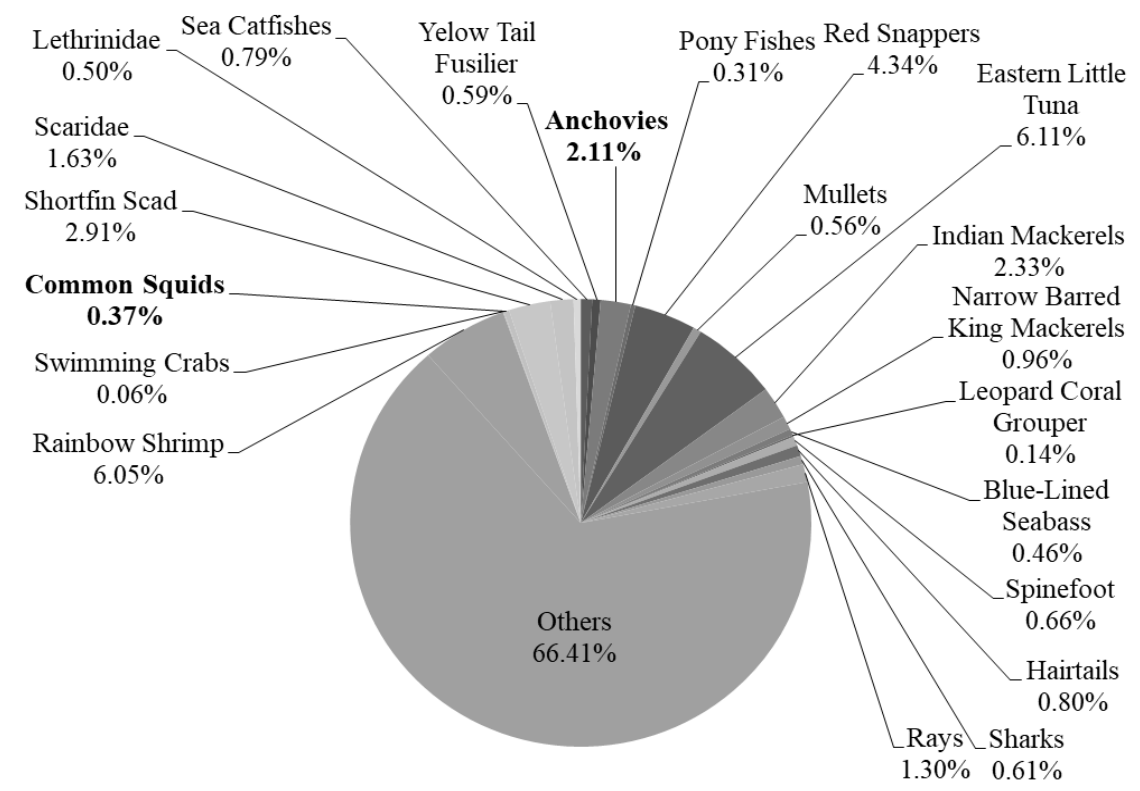

Figure 3. The composition of marine fisheries commodity in Jepara District, Central Java, Indonesia, 2019 (DMF of Jepara District 2020)

Squids belong to the Class Cephalopods. Cephalopods have several orders, including Sepioidea, Teuthoidea, and Octopoda. According to Roper et al. (1984), squids have the Order Teuthoidea. The Genus Loligo belongs to the Order Teuthoidea. Several Species Loligo found in Indonesian waters includes Loligo chinensis (mitre squid), L. duvaucelii (Indian squid), L. edulis (Swordtip squid), and L. singhalensis (Long Barrel squid). The Genus Sepioteuthis is also part of the Order Teuthoidea, including Sepioteuthis lessoniana (Bigfin Reef squid), which also lives in Indonesian waters. Meanwhile, the Order Sepioidea has the commercial name of Cuttlefishes. Some species of the Order Sepioidea found in Indonesian waters include Sepia aculeata (Needle Cuttlefish), Sepia brevimana (Shortclub Cuttlefish), Sepia latimanus (Broadclub Cuttlefish), Sepia lycidas (Kisslip Cuttlefish), Sepia pharaonis (Pharaoh Cuttlefish), and Sepia recurvirostra (Curvespine Cuttlefish). Octopods has the commercial name Octopuses. Several species of the Order Octopods are found in Indonesian waters include Octopus vulgaris (common Octopus), $O$. aegina (Sandbird octopus), and $O$. cyanea (Big Blue Octopus). In Indonesia, squids are called 'Cumi-cumi', cuttlefishes are called 'Sotong,' and octopuses are called 'Gurita'. However, in data collection in several regions in Indonesia, the three (squids, cuttlefishes, and octopuses) marine biota are used as one data group, namely squids, including in Jepara District.

Anchovies (Stolephorus sp) is part of the Sub-Order Clupeoidei, Family Engraulididae, and Sub-Family Engraulidinae, which have 13 genera (Whitehead et al. 1988). According to Fitri et al. (2018), there are nine anchovy types in the Indonesian waters. Several species of anchovy found in Indonesian waters include: Stolephorus commersonnii (Commerson's anchovy), S. andhraensis (Andhra anchovy), S. baganensis (Bagan anchovy), S. insularis (Hardenberg's anchovy), S. dubiosus (Thai anchovy), S. indicus (Indian anchovy), S. waitei (Spottyface anchovy) and $S . t r i$ (Spined anchovy). 


\section{The CPUE progress of anchovies and squids}

The CPUE (catch per unit effort) of anchovies and squids in the Jepara District has fluctuated (Figure 4). CPUE indicates the availability of marine biota resources. Figure 2 and Figure 3 show this relationship pattern, suggesting an ecological relationship between the two in its production and CPUE. Research by Martins and Perez (2006) showed that the use of lights at night attracts plankton, small clupeiform fish (including anchovies), squids (Loligo plei, L. sanpaulensis and Lolliguncula brevis) and Trichiurus lepturus. The relationship between these types of biota is a predator-prey relationship.

\section{The production function and optimization}

This research showed a relationship between the production of squids and anchovies fish (predator-prey). Equations [10] and [11] represents this relationship. Production of squids has a positive impact on anchovies production. However, the production of anchovies harms squids' production.

$$
\begin{aligned}
& C_{A}=14,507 E-51 E^{2}+0.41 C_{S} \\
& C_{S}=35,156 E-124 E^{2}-2.42 C_{A}
\end{aligned}
$$

By referring to equations [6] and [7], therefore, equations [10] and [11] can be modified into equations [12] and [13]. The projection of optimum fishing efforts to maximize anchovies production and squid production is presented in Table 1. The simulation of equations [10] (with modified without the existence of squid production), [11], and (13) available in Figure 5.

$$
\begin{aligned}
& C_{A}=4,444 E-15.49 E^{2} \\
& C_{S}=24,385 E-86.54 E^{2}
\end{aligned}
$$

\section{Discussion}

Fishers from Jepara District catch squids using a lift net. Squids are also caught using purse seine and seine net. However, squids are not the main catch of purse seine and seine net. In predator-prey modeling, including the case of

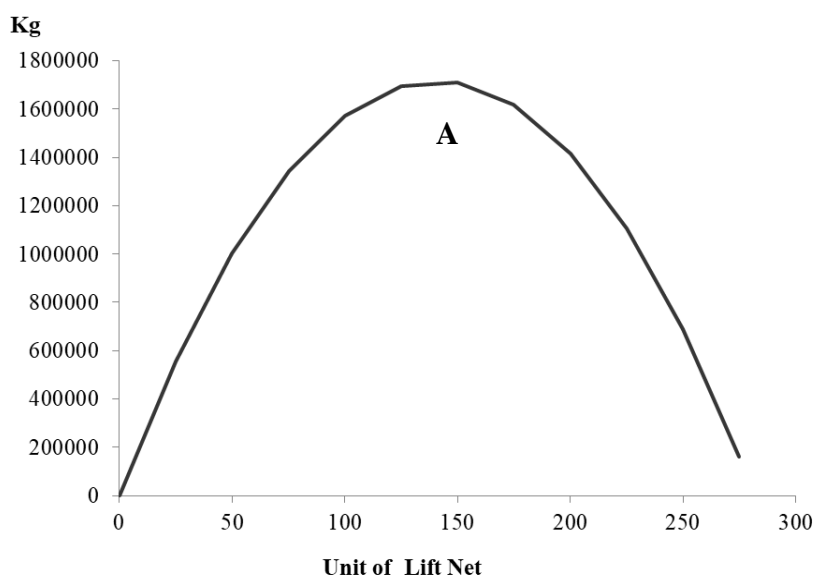

squids and anchovies, all fishing gears that catch squids and anchovies must be taken into account by standardizing fishing efforts. In principle, the catch of squids (as a predator of anchovies) can increase anchovies' population so that anchovies production can increase. The catch of anchovies (as prey for squids) can reduce squids' population, reducing the catch of squids. Mathematically (based on equation 10 and equation 11), catching $1 \mathrm{~kg}$ of squid can increase anchovies' catch by $0.41 \mathrm{~kg}$.

Table 1. The simulation of optimization

\begin{tabular}{|lcc|}
\hline The optimal fishing effort & Units of lift net & Production (kg) \\
\hline Production of anchovies & 144 & 318,899 \\
Production of squids & 141 & $1,717,747$ \\
\hline
\end{tabular}

Note: The lift net is assumed as the standard of fishing effort. One unit of purse seine's fishing power is equal to 20.8 units of lift net, and one unit of demersal Danish seine is equal to 0.08 units of lift net to catch the squid (on average in 2010 to 2019). One unit of demersal Danish seine's fishing power is equal to a $\$ 0.004$ unit of lift net to catch the anchovy (on average in 2010 to 2019).

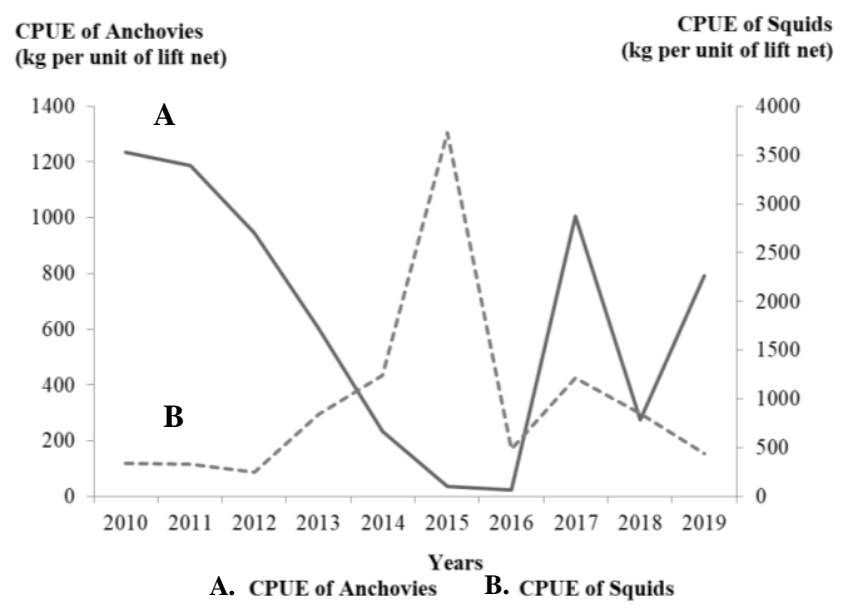

Figure 4. The progress of CPUE of squid and CPUE of anchovy

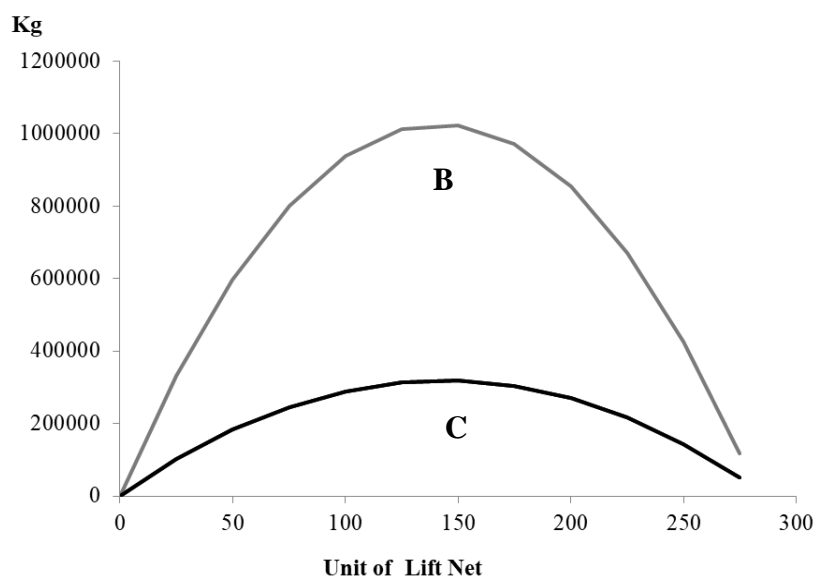

Figure 5. The production simulation of squid and anchovy. Note: A. Squids production: $\mathrm{C}_{\mathrm{S}}=24,385 \mathrm{E}-86 \mathrm{E}^{2}$; B. Anchovies production (without the existence of squids with $\mathrm{C}_{\mathrm{S}}=0$ ): $\mathrm{C}_{\mathrm{A}}=14,507 \mathrm{E}-51 \mathrm{E}^{2} 0.41 \mathrm{C}_{\mathrm{S}}$; $\mathrm{C}$. Anchovies production (with the existence of squids): $\mathrm{C}_{\mathrm{A}}$ $=4,444 \mathrm{E}-15 \mathrm{E}^{2}$ 
Meanwhile, $1 \mathrm{~kg}$ of anchovies can reduce the catch of squid by $2.42 \mathrm{~kg}$. The simulation in this study showed that without squids as a predator, the catch of anchovies is greater than the production of anchovies when the model considers the presence of squids (can be seen in Figure 5.B and Figure 5.C). In the wild, the population and production relationship between anchovies and squids are complex because many factors influence the variables that are examined in this study. According to the Schaefer model, fisheries production depends on several factors, including the intrinsic growth rate of fish, environment carrying capacity, fishing power of fishing gear, and fish biomass stock. Environment carrying capacity also depends on several factors, including space, dissolved oxygen, temperature, and natural feed (Schaefer 1957; Wijayanto et al. 2020a).

Lift net in Indonesia is the main gear for anchovies fishing. The research of Sulaiman et al. (2015) showed that anchovies (Stolephorus insularis and $S$. indicus) and squids (Loligo sp.) are the dominant catches from lift nets in the Makassar Strait (Indonesia). Meanwhile, the other dominant fish catches are Decapterus ruselli, Rastrelliger canagurta, Sardinella fimbriata, and Leiognatus aureus. While the research of Tejo et al. (2020) showed that the catch of boat lift nets in Belitung District waters is Sardinella fimbriata, Sardinella sirm, Stolephorus devisi, Loligo sp., Rastrelliger brachysoma, Leiognathus equulus, Trichiurus sp., Selaroides leptolesis, Sphyraena sp., and Tetraodo sp.

Anchovies are pelagic-neritic fish that can live in the sea with a depth of 0 to $50 \mathrm{~m}$ (Whitehead et al. 1988). Surface plankton is the anchovies' food, including copepods and prawn larvae (Robins et al. 1991). According to Roper et al. (1984), squids feed on fishes, crustaceans, and other squids (cannibal).

According to Fuad et al. (2019), anchovies as planktoneater fish are attracted to light and continuously swarm around the light. Nevertheless, squids and other predators will leave the area when the small fish leave. Squids as predators are attracted to light because of anchovies and other small plankton-eater fish around the light. While the research of Ibrahim and Hajisamae (1999) on squids showed that Sepioteuthis lessoniana has a higher positive phototaxis than Loligo chinensis. According to Arnupapboon et al. (2008), squids (Loligo dauvauceli and L. chainensis) are attracted to white and blue light more than green and red. In nature, blue light can penetrate deeper seawater than other colors.

The fish resources in Java Sea (as the fishing ground of fishermen from Jepara District) have links between one type of fish and another, including predator-prey, food competition and mutually beneficial relationships (Wijayanto et al. 2020b). This research proved a predatorprey relationship between squids (as predator) and anchovies fish (as prey) in Jepara District. The production function of anchovies fish in the Jepara District is influenced by the number of lift net (unit) and the production of squids. The production function of squids is also influenced by the number of lift net (unit) and anchovies production. The optimal level of fishing effort for anchovies production is 144 units of lift net, and the optimal level of fishing effort for squids production is 141 units of lift net.

Deng's (2019) 's research using the Lotka-Volterra predator-prey model proved if predatory fish and prey fish coexist in stable conditions in nature. Therefore predator fish can cause the prey fish to become extinct. Cannibalism by a predator has a positive and negative effect on the stability of the natural system. Lotka-Volterra model is one of the pioneers in the prey-predator model that it developed in the 1920s. According to Wikan and Kristensen (2019), the Lotka-Volterra model consists of a system of two coupled nonlinear differential equations, but the model has structurally unstable; applying the model to real-world phenomena is likely to fail. In principle, every model is a simplification of reality. All models have weaknesses, but the models can efficiently support planning activities and the evaluation process of policy.

Lift net fishers use fishing lamps to attract fish schooling with phototaxis positive properties, including anchovies and squids (Susanto et al. 2017). In multi-species fisheries, increased capture of prey species can affect other species (Purohit and Chaudhuri 2004; Nieminen 2012; Vidyanath et al. 2017; Wijayanto et al. 2020a). In making a multi-gear fisheries policy, a comprehensive study is needed. The policy for specific fishing gear may affect other fishing gears (Wijayanto et al. 2019a, b; Wijayanto et al. 2020b). According to Pelletier et al. (2009), fish resources management needs to be evaluated using resource indicators (including abundance and biomass) and economic indicators (including marketing margin and profit).

The research of Tejo et al. (2020) showed that the boat lift net is classified as less environmentally friendly because $48 \%$ of fish caught is not mature. According to Solomon and Ahmed (2016), the use of artificial light can attract fish and increase fish catches, but it can also deplete fish resources and degrade coral reefs. Artificial lights are also not environmentally friendly due to the capture of immature stocks, high bycatch rates, and have green gas emission issues. Therefore, the lift net policy is needed. The production of anchovies needs to be controlled because it will affect the stocks of anchovies predator and the food chain in the holistic. The lift net is also not able to catch fish selectively because it also catches juvenile fish.

\section{ACKNOWLEDGEMENTS}

Our research team is grateful for the funding support from the Ministry of Research and Higher Education of Indonesia. This research was funded through a basic research grant with contract numbers 22563/UN7/6/1/PP/2020. We also thank the Department of Marine and Fisheries (DMF) of Jepara District for providing data in this research. 


\section{REFERENCES}

Arnupapboon S, Awaiwanont K, Anongponyoskun M, Annanpongsuk S, Chokesanguan B. 2008. Boosting the development of responsible squid light fishery: Assessment of squid feeding behavior. Fish People 6 (1): 44-47.

BPS-Statistics of Jepara District 2020. Jepara District in Figures 2020. BPS-Statistics of Jepara District, Indonesia.

Deng H, Chen F, Zhu Z, Li Z. 2019. Dynamic behaviors of LotkaVolterra predator-prey model incorporating predator cannibalism Adv Differ Equ 2019: 359. DOI: 10.1186/s13662-019-2289-8

DMF of Jepara District. 2020. Fisheries Data. Department of Marine and Fisheries (DMF) of Jepara District, Indonesia. [Indonesian]

FAO. 2016. Technical and Socio-Economic Characteristics of Small-Scale Coastal Fishing Communities, and Opportunities for Poverty Alleviation And Empowerment. Food and Agriculture Organization (FAO) of The United Nations, Rome, Italy.

Fitri ADP, Ramadanita IA, Hapsari TD, Susanto A. 2018. Stolephorus sp behavior in different LED (Light Emitting Diode) color and light intensities. IOP Conf Ser Earth Environ Sci 116: 012067. DOI: 10.1088/1755-1315/116/1/012067

Fuad, Baskoro MS, Riyanto M, Mawardi W. 2019. Catch characteristics on stationary lift net using light-emitting diode (LED) and kerosene lights in Pasuruan waters. AACL Bioflux 12 (2): 490-501.

Ibrahim S, Hajisamae S. 1999. Response of squids to different colours and intensities of artificial light. Pertanika J Trop Agric Sci 22 (1): 19-24.

Martins RS, Perez JAA. 2006. Behavior of cephalopod and fish under night lights cephalopods and fish attracted by night lights in coastal shallow-waters, off Southern Brazil, with the description of squid and fish behavior. Revista de Etologia 8 (1): 27-34.

Nieminen E. 2012. Optimal bioeconomic multi-species fisheries management: a Baltic Sea case study. Mar Resour Econ 27 (2): 115 136.

Pelletier D, Mahevas S, Drouineau H, Vermard Y, Thebaud O, Guyader O, Poussin B. 2009. Evaluation of the bioeconomic sustainability of multi-species multi-fleet fisheries under a wide range of policy options using ISIS-Fish. Ecol Model 220 (7): 1013-1033.

Purohit D, Chaudhuri KS. 2004. A bioeconomic model of nonselective harvesting of two competing fish species. ANZIAM J 46 (2): 299308 .

Robins CR, Bailey RM, Bond CE, Brooker JR, Lachner EA, Lea RN, Scott WB. 1991. World Fishes Important to North Americans. Exclusive of Species from the Continental Waters of the United States and Canada. American Fisheries Society, USA.
Roper CFE, Sweeney MJ, Nauen CE. 1984. FAO Species Catalogue. Vol. 3. Cephalopods of the World. An Annotated and Illustrated Catalogue of Species of Interest to Fisheries. FAO Fish, FAO, Rome.

Schaefer MB. 1957. A study of the dynamics of the fishery for yellowfin tuna in the Eastern Tropical Pacific Ocean. Inter-Am Trop Tuna Comm Bull 2 (6): 243-285

Solomon OO, Ahmed OO. 2016. Fishing with light: Ecological consequences for coastal habitats. Intl J Fish Aquat Stud 4 (2): 474483.

Sulaiman M, Baskoro MS, Taurusman MA, Wisudo SH, Yusfiandayani R. 2015. Relationship of catching and oceanographic parameters of boat lift net (bagan pete-pete) using mercury lamp and led lamp. Intl J Sci Basic Appl Res 20 (1): 228-239.

Susanto A, Irnawati R, Mustahal, Syabana MA. 2017. Fishing efficiency of LED lamps for fixed lift net fisheries in Banten Bay, Indonesia. Turkish J Fish Aquat Sci 17: 283-291. DOI: 10.4194/1303-2712v17_2_07.

Tejo SBA, Supriadi D, Rostika R, Khan AMA. 2020. The environmental friendliness level of boat bagan fishing gear in Belitung Regency. Asian J Fish Aquat Res 8 (3): 17-27. DOI: 10.9734/AJFAR/2020/v8i330140.

Vidyanath T, Lakshmi NK, Bathul S. 2017. Bionomic equilibrium of a three-species model with optimal harvesting for the first prey. Intl $\mathrm{J}$ Pure Appl Math 113 (9): 220-233.

Whitehead PJP, Nelson GJ, Wongratana T. 1988. FAO Species Catalogue. Vol. 7. Clupeoid fishes of the world (Suborder Clupeoidei). An annotated and illustrated catalogue of the herrings, sardines, pilchards, sprats, shads, anchovies and wolf-herrings. FAO Fish, FAO, Rome.

Wijayanto D, Bambang AN, Kurohman F. 2020a. The multi-species model of fringscale sardinella and largehead hairtail in Rembang Regency, Indonesia. AACL Bioflux 13 (4): 2312-2319.

Wijayanto D, Setiyanto I, Setyawan HA. 2020b. Bio-economic model of Danish seine and purse seine fisheries in Rembang Regency, Indonesia. Egypt J Aquat Res 46 (1): 63-70.

Wijayanto D, Sardiyatmo, Setyanto I, Kurohman F. 2019a. Bioeconomic analysis of the impact of 'cantrang' (Danish seine) toward gill net in Pati Regency, Indonesia. AACL Bioflux 12 (1): 25-33.

Wijayanto D, Bambang A N, Kurohman F. 2019b. The impact of 'cantrang' (Danish seine) fisheries on gillnet fisheries in Tegal coastal area, Indonesia. AACL Bioflux 12 (4): 1005-1014.

Wikan A, Kristensen Ø. 2019. Prey-predator interactions in two and three species population models. Discrete Dyn Nat Soc 2019: 9543139. DOI: $10.1155 / 2019 / 9543139$ 